\title{
Dr. Jack Tu, a research superstar ahead of his time (1965-2018)
}

- Cite as: CMAJ 2018 June 25;190:E780-1. doi: 10.1503/cmaj.109-5620

Posted on cmajnews.com on June 8, 2018.

n 1992, Dr. Jack Tu, a graduate student and internal medicine resident at Sunnybrook Health Sciences Centre, settled nervously in the office of Dr. David Naylor, then in his first year as CEO of the Institute for Clinical Evaluative Sciences (ICES). Tu was there to ask Naylor to supervise his Masters thesis, about using analytics to improve cardiac care.

He had a "gap-toothed grin that lit up his whole face," Naylor said in a speech delivered at the recent funeral for Tu, a professor, clinician, world-renowned researcher, husband and father, who died unexpectedly on May 30 at age 53.

Tu was quiet, but once he launched into his research ideas, he began to speak quickly and passionately. Naylor was amazed by his curiosity, his intelligence and his meticulous research plan. But he was a bit taken aback when Tu started talking about artificial intelligence algorithms.

"Neural networks were still in their infancy," Naylor told the crowd gathered in Toronto. "Yet somehow Jack, as a fulltime internal medicine resident, was already up to speed on their possible applications."

In 1996, Tu published a paper on the advantages and disadvantages of neural networks and logistic regression in modelling health outcomes. That paper "languished in obscurity," but began to get noticed about a dozen years later and has since been cited almost 1000 times. "Jack was simply too far ahead of his time," said Naylor.

Tu remained at the vanguard with his subsequent research projects. In 2001, he made partnerships with scientists around the country, leading to the Canadian Cardiovascular Outcomes Research Team (CCORT).
"He could have used the Ontario dataset he had access to, but he engaged with people outside of the province, and that's quite unusual for a young guy," said Dr. Andreas Laupacis, a professor at the University of Toronto in the Department of Medicine and the Institute of Health Policy, Management and Evaluation. health of Ontarians and Canadians was gratitude to the country that welcomed his parents, who emigrated from Taiwan when Tu was only two years old.

Tu didn't want to only understand health disparities; he wanted to find solutions. In one case, he and his team conducted an award-winning trial, during

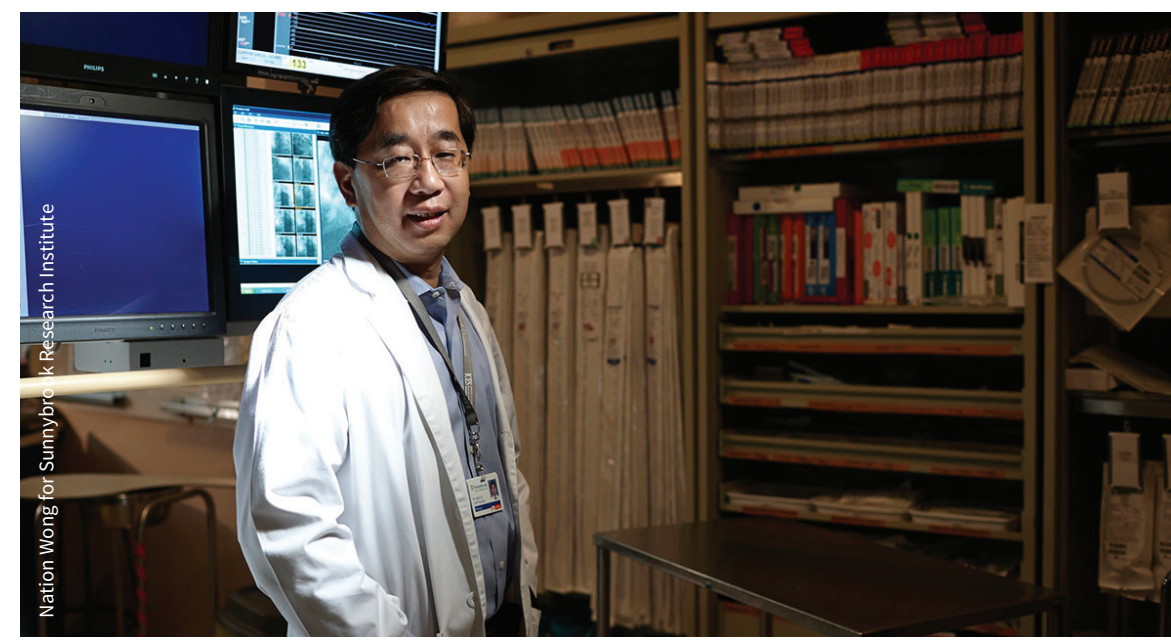

World-renowned researcher Dr. Jack Tu died unexpectedly at age 53.

The results showed considerable regional and provincial variation in the quality of cardiovascular care. "Now, we all know that practice variation depends on geography but it wasn't known then," said Laupacis. "It was really a landmark study."

Dr. Louise Pilote, professor of medicine at McGill University, and a senior scientist with the Cardiovascular Health Across the Lifespan Program, was the Quebec CCORT research lead. "He really had a vision to improve cardiovascular outcomes," said Pilote. "It was because of his passion that people wanted to work with him. It was exciting to be near him."

Pilote is not sure, but she wonders if part of Tu's burning desire to better the which he randomized some hospitals to receive public report cards on cardiac care and others to receive no feedback. The results showed that report cards didn't affect quality. Dr. Michael Schull, CEO of ICES, said the data challenged conventional thinking at the time. "It showed that just feeding back reports on performance doesn't necessarily drive improvement. It's more complicated than that."

His later research, using data collected by the Cardiovascular Health in Ambulatory Care Research Team (CANHEART), challenged another widespread belief, that raising HDL, or "good" cholesterol, could improve mortality. Tu was able to realize his big-data ambitions 
as co-principal investigator of CANHEART. $\mathrm{He}$ and his colleagues brought together administrative, laboratory, clinical and electronic health record data with the hopes of better understanding and improving community-based care. Tu was known for his ability to meld datasets with vastly different reporting standards. "He was a data magician," said Pilote.

Tu published hundreds of peerreviewed articles in his career, including 48 in CMAJ. He published 130 papers in the last five years. Peter Austin, a senior scientist at ICES, said Tu often reinvented himself as a researcher. "After working in one area for several years, he would turn his focus to a completely different area." He involved many other scientists in his projects and was uniquely generous about sharing data, "which is like gold in our research area," said Austin.
Tu also saw patients at the division of cardiology in the Schulich Heart Program at Sunnybrook and taught in the Department of Medicine at the University of Toronto.

Dr. Harindra Wijeysundera was one of Tu's mentees and later became a colleague at ICES. "He was understated, and humble," said Wijeysundera. If you didn't already know of his accomplishments, "you would never know you were in a room with this superstar world-renowned researcher," said Wijeysundera.

Tu had "extremely high standards and was very principled," said Wijeysundera. And when his research team would go out for dinner, Tu would talk about how important his wife and son were to him.

Schull said Tu would always leave his office door open so colleagues and junior researchers could enter to discuss projects. "Staff really appreciated that avail- ability, that willingness to sit with them and work through the problems together," Schull said. "He had an incredible gentleness and generosity."

Pilote remembers Tu telling her about how difficult it was when some of his cardiovascular colleagues across the country took offense to his CCORT research on care quality variations. "I was surprised to hear he had ever had conflicts, because he was so private," said Pilote. "He was very sensitive. He always wanted to please everyone."

As Wiseysundera put it, "with Jack, it wasn't just winning the game, it was how you played it. You played fair, you played to high standards, and people admired Jack not just because he was so successful, but because of the manner in which he achieved that."

Wendy Glauser, Toronto, Ont. 